\title{
Paediatric versus adult trauma car accidents mortality in a northern Italy trauma system
}

\author{
A Giugni ${ }^{*}$, L Giuntoli ${ }^{2}$ F Del Corso ${ }^{1}$, F Mengoli ${ }^{1}$, A Volpi ${ }^{3}$, E Bigi ${ }^{1}$, M Menarini ${ }^{1}$, A Maioli ${ }^{1}$, M Grazia ${ }^{1}$, C Simonetti ${ }^{1}$, \\ I Turriziani ${ }^{1}$, A Chieregato $^{4}$, G Gordini $^{1}$
}

From London Trauma Conference 2012

London, UK. 4-7 December 2012

\section{Background}

Trauma accounts for a large proportion of childhood mortality. Few data exist about injury patterns within paediatric trauma in Italy. Recognizing high-risk patterns may help to improve care and outcome[1].

\section{Methods}

Data from the 315 ( $<17$ years old) major trauma cases collected in the Emilia-Romagna trauma registry (RRTG) since 2006 to 2010 were analyzed. The inclusion criteria are ISS $>15$ or Intensive Care Unit (ICU) admission, which is decided by clinical judgment without standard criteria. In Emilia Romagna there are no Paediatric Trauma Centers. The main outcome measure [2] was mortality at discharge from the ICU. Patients dead on arrival or early in the Emergency Room were not considered. Injury severity was coded according to the '98 AIS version.

\section{Results}

There were 315 (90 cases/y) paediatric cases; mean age was $11.79 \pm 5.34$ (median 14 , IQR $95 \% 8$ ) years. In the same period 3575 patients older than 16 years were included; mean age was $49.86 \pm 21.01$ (median 47 , IQR $95 \% 37$ ) years. The overall mortality was $7.1 \%$ for children, and $12.9 \%$ for adults; the difference was significant $(\mathrm{p}=0.0005)$. The commonest mechanism of injury (MOI) was road traffic accident (RTA). Car crashes (CC) accounted for $30.2 \%$ of RTAs for patients under 17 , and for $39.3 \%$ for those older than 16 . Mortality for CC was $11.6 \%$ among children, and $9.0 \%$ among adults, with no difference $(\mathrm{p}=0.3913)$.

The mortality for CC is shown in Table 1, stratified by ISS and age.

A difference was observed for ISS 41-75 class; children mortality resulted significantly higher than the one of adults. $(\mathrm{p}=0.0373)$.

\section{Conclusion}

Many severe RTAs injuries are caused by CC, both in children and in adults. The overall mortality is significantly higher in adults, while CC mortality is similar in the two groups, except for the most severely injured patients, where it is worse in the younger.

Some questions remain open, thus needing further investigations:

-are paediatric safety systems widely and properly used by adults when transporting children in their cars?;

-are children more exposed to lethal lesions often travelling as passengers, and being unaware of the imminent crash, consequently unprepared to counteract deceleration?

Table 1

\begin{tabular}{lllllllllllll}
\hline & ISS $\mathbf{1 - 1 5}$ & \multicolumn{3}{c}{ ISS $\mathbf{1 6 - 2 4}$} & \multicolumn{3}{c}{ ISS $\mathbf{2 5 - 4 0}$} & \multicolumn{3}{c}{ ISS $\mathbf{4 1 - 7 5}$} \\
\hline & deaths & total & mortality & deaths & total & mortality & deaths & total & mortality & deaths & total & mortality \\
\hline $\mathbf{2 1 7}$ years & 8 & 165 & 4.8 & 22 & 549 & 4.0 & 41 & 480 & 8.5 & 51 & 200 & 25.5 \\
\hline $\mathbf{1} \mathbf{1 7}$ years & 0 & 18 & 0 & 0 & 28 & 0 & 4 & 34 & 11.8 & 7 & 14 & 50 \\
\hline
\end{tabular}

${ }^{1}$ Maggiore Hospital Emergency Department and Trauma Care, Bologna, Italy

Full list of author information is available at the end of the article

C 2013 Giugni et al; licensee BioMed Central Ltd. This is an Open Access article distributed under the terms of the Creative Commons 
-is the ISS reliable for paediatric patients (who have a higher incidence of head injuries)?[3] This score assigns the same weight to all body regions, disregarding the importance of head injuries in mortality;

-are adult trauma centers prepared to deal with severely injured children, given their rare occurrence? Should caregivers usually working on adults receive an additional specific paediatric training?

Future analyses of RRTG may help to evaluate both outcomes and management of high- risk children, and to improve the quality of care.

\section{Author details}

${ }^{1}$ Maggiore Hospital Emergency Department and Trauma Care, Bologna, Italy. ${ }^{2}$ Maggiore Hospital Anesthesia and intensive care unit, Bologna, Italy.

${ }^{3}$ Maggiore Hospital Intensive Care Unit, Parma, Italy. ${ }^{4}$ Bufalini Hospital NeuroIntensive Care Unit, Cesena, Italy.

Published: 28 May 2013

\section{References}

1. Bayreuther J: Paediatric trauma: injury pattern and mortality in the UK. Arch Dis Child Educ Pract Ed 2009, 94:37-41.

2. Knoester $\mathrm{H}$ : Outcome of paediatric intensive care survivors. Eur J Pediatr 2007, 166:1119-28.

3. Palmer C: Major trauma and the injury severity score-where should we set the bar? Annu Proc Assoc Adv Automot Med.

doi:10.1186/1757-7241-21-S1-S2

Cite this article as: Giugni et al:: Paediatric versus adult trauma car accidents mortality in a northern Italy trauma system. Scandinavian Journal of Trauma, Resuscitation and Emergency Medicine 2013 21(Suppl 1): S2.

\section{Submit your next manuscript to BioMed Central} and take full advantage of:

- Convenient online submission

- Thorough peer review

- No space constraints or color figure charges

- Immediate publication on acceptance

- Inclusion in PubMed, CAS, Scopus and Google Scholar

- Research which is freely available for redistribution

Submit your manuscript at www.biomedcentral.com/submit 